\title{
Personal Guarante Terhadap Perjanjian Kredit Dengan Jaminan Hak Tanggungan
}

\author{
Murlyta Nevi Sukmawarti, SH \\ Nevisukma.mns@gmail.com \\ Fakultas Hukum Universitas Airlangga
}

\begin{abstract}
Abstrak
Didalam pengaturan Hukum Keperdataan Personal guarantee termasuk kedalam kategori penanggungan utang yang dalam sistem hukum nasional kita diatur dalam Pasal 1820-1850 Burgerlijk Wetboek (Selanjutnya disebut BW). Dalam Pasal 1820 BW disebutkan bahwa yang dimaksud dengan penanggungan adalah suatu perjanjian, dimana pihak ketiga, demi kepentingan kreditor, mengikatkan dirinya untuk memenuhi perikatan debitur, bila debitor itu tidak memenuhi perikatannya. Debitor dalam mengajukan utang tidak jarang untuk dimintai jaminan sebagai bentuk perlindungan terhadap terhadap hak kreditor. Tetapi dalam hal ini biasanya yang dijadikan objek jaminan bukan merupakan benda yang dimiliki oleh debitor melainkan pihak ketiga. Dalam lembaga jaminan hak tanggungan sering ditemukan bahwa pihak yang menjaminkan tanahnya sebagai objek hak tanggungan bukanlah si debitor, melainkan pihak ketiga diluar perjanjian kredit yang secara sukarela mengikatkan dirinya. Dalam hal ini penulis akan menyajikan penelitian secara normatif tentang Personal Guarantee dalam perjanjian kredit dengan jaminan Hak Tanggungan.
\end{abstract}

\section{PENDAHULUAN}

\section{Latar Belakang}

Bank dalam Undang-Undang Nomor 10 Tahun 1998 tentang Perubahan Atas Undang-Undang Nomor 7 Tahun 1992 tentang Perbankan (Selanjutnya disebut Undang-Undang Perbankan) didefinisikan sebagai badan usaha yang menghimpun dana dari masyarakat dalam bentuk simpanan dan menyalurkannya kepada masyarakat dalam bentuk kredit dan atau bentuk-bentuk lainnya dalam rangka meningkatkan taraf hidup rakyat banyak. Dari pengertian Bank tersebut, maka Bank memiliki peranan penting untuk menunjang perekonomian nasional, dan juga mengemban tugas serta amanat pembangunan bangsa demi tercapainya peningkatan taraf hidup rakyat. Untuk melaksanakan visi dan misi tersebut, Bank berperan sebagai Intermediary Institution. Sebagai lembaga perantara keuangan masyarakat (intermediary institution), bank menjadi media perantara pihak pihak yang memiliki kelebihan dana (surplus of funds) dengan pihak-pihak yang 
kekurangan dana (lack of found). ${ }^{1}$ dengan menyelenggarakan fungsi-fungsi sebagai berikut: ${ }^{2}$

1. Fungsi menghimpun dana;

2. Fungsi pemberian kredit;

3. Fungsi memperlancar lalu lintas pembayaran;

4. Fungsi sebagai penyedia informasi, pemberian konsultasi dan bantuan penyelenggaraan administrasi.

Dalam proses pemberian kredit, tentulah pihak bank tidak semerta-merta begitu saja memberikan pinjaman kepada siapapun. Disini, ada kriteria-kriteria yang harus dipenuhi untuk dapat mendapatkan pinjaman dari bank. Kriteriakriteria ini merupakan prinsip-prinsip pemberian kredit.

Menurut Kasmir ada beberapa prinsip-prinsip penilaian kredit yang sering dilakukan yaitu dengan analisis $5 \mathrm{C}$, yang terdiri atas :

a Character, adalah sifat atau watak seseorang dalam hal ini adalah calon debitur. Tujuannya adalah untuk memberikan keyakinan kepada Bank, bahwa sifat atau watak dari orang-orang yang akan diberikan kredit benarbenar dapat dipercaya.

b Capacity (capability), untuk melihat kemampuan calon nasabah dalam membayar kredit dihubungkan dengan kemampuan mengelola bisnis serta kemampuan mencari laba.

c Capital,dimana untuk mengetahui sumber-sumber pembiayaan yang dimiliki nasabah terhadap usaha yang akan dibiayai oleh Bank.

d Collateral, merupakam jaminan yang diberikan calon nasabah baik yang bersifat fisik maupun non fisik. Jaminan hendaknya melebihi jumlah kredit yang diberikan.

e Condition, dalam menilai kredit hendaknya dinilai kondisi ekonomi sekarang dan untuk dimasa yang akan datang sesuai sektor masingmasing. ${ }^{3}$

Kemudian penilaian kredit dengan metode analisis $7 \mathrm{P}$ menurut Kasmir adalah sebagai berikut :

1. Personality, yaitu menilai nasabah dari segi kepribadiannya atau tingkah lakunya sehari-hari maupun masa lalunya. Personality juga mencakup

${ }^{1}$ Ibid., h. 29.

${ }^{2}$ Neni Sri Imaniyanti, Pengantar Hukum Perbankan Indonesia, Refika Aditama, 2010, Bandung, 13

${ }^{3}$ Kasmir,Bank dan Lembaga Keuangan Lainnya, Jakarta, Rajawali Pers, 2012, h. 95. 
sikap, emosi, tingkah laku, dan tindakan nasabah dalam menghadapi suatu masalah.

2. Party, yaitu mengklasifikasikan nasabah ke dalam klasifikasi tertentu atau golongan-golongan tertentu berdasarkan modal, loyalitas serta karakternya. Sehingga nasabah dapat digolongkan ke golongan tertentu dan akan mendapatkan fasilitas yang berbeda dari bank.

3. Purpose, yaitu untuk mengetahui tujuan nasabah dalam mengambil kredit, termasuk jenis kredit yang di inginkan nasabah. Tujuan pengambilan kredit dapat bermacam-macam. Sebagai contoh apakah untuk modal kerja atau investasi, konsumtif atau produktif, dan lain sebagainya.

4. Prospect, yaitu untuk menilai usaha nasabah di masa yang akan datang menguntungkan atau tidak, atau dengan kata lain mempunyai prospek atau sebaliknya. Hal ini penting mengingat jika suatu fasilitas kredit yang di biayai tanpa mempunyai prospek, bukan hanya bank yang rugi, tetapi juga nasabah.

5. Payment, merupakan ukuran nasabah bagaimana cara nasabah mengembalikan kredit yang telah di ambil atau dari sumber mana saja dana untuk pengembalian kredit.

6. Profitability untuk menganalisis bagaimana kemampuan nasabah dalam mencari laba. Profitability diukur dari periode ke periode apakah akan tetap sama atau akan semakin meningkat, apalagi dengan tambahan kredit yang akan diperolehnya.

7. Protection, tujuannya adalah bagaimana menjaga agar usaha dan jaminan mendapatkan perlindungan. Perlindungan dapat berupa jaminan berupa jaminan barang atau orang atau jaminan asuransi. ${ }^{4}$

Selanjutnya penilaian kredit dengan metode analisis $3 \mathrm{R}$ menurut Hasibuan sebagai berikut :

1. Returns adalah penilaian atas hasil yang akan dicapai perusahaan calon debitur setelah memperoleh kredit. Apabila hasil yang diperoleh cukup untuk membayar pinjamannya dan sekaligus membantu perkembangan usaha calon debitur bersangkutan maka kredit diberikan. Akan tetapi, jika sebaliknya maka kredit jangan diberikan.

2. Repayment adalah memperhitungkan kemampuan, jadwal, dan jangka waktu pembayaran kredit oleh calon debitur, tetapi perusahaannya tetap berjalan.

3. Risk Bearing Ability adalah memperhitungkan besarnya kemampuan perusahaan calon debitur untuk menghadapi risiko, apakah perusahaan

${ }^{4}$ Ibid, h. 96. 
calon debiturnya risikonya besar atau kecil. Kemampuan perusahaan menghadapi risiko ditentukan oleh besarnya modal dan strukturnya, jenis bidang usaha, dan manajemen perusahaan bersangkutan. Jika risk bearing ability perusahaan besar maka kredit tidak diberikan, tetapi apabila risk bearing ability perusahaan kecil maka kredit diberikan. ${ }^{5}$

Untuk pemberian kredit, tidak bisa dilepaskan dari prinsip Collateral atau di sini dikenal dengan sebutan jaminan. Jaminan merupakan suatu langkah penting dalam langkah-langkah menjaga keamanan kredit bank. Langkah pengamanan ini dilakukan sedemikian rupa oleh karena pemberian kredit terkait dengan suatu resiko (degree of risk) atau setidak-tidaknya memperkecil resiko yang timbul. Oleh karena itu bank dilarang memberikan kredit tanpa jaminan sesuai dengan bunyi pasal 2 ayat 1 Surat Keputusan Direksi Bank Indonesia Nomor 23/69/KEP/DIR tanggal 28 Februari 1991 tentang Jaminan Pemberian Kredit. Karena kredit yang diberikan oleh bank mengandung resiko, sehingga dalam pelaksanaannya bank harus memperhatikan asas-asas perkreditan yang sehat. $^{6}$

Dalam Undang-Undang Nomor 10 Tahun 1998 tentang Perbankan (Selanjutnya disebut Undang-Undang Perbankan), jaminan tidak merupakan syarat mutlak, karena itu ketentuan Pasal 8 Undang-Undang Perbankan memungkinkan untuk memberikan kredit tanpa jaminan. Jaminan dalam arti collateral di sini hanya merupakan salah satu syarat yang harus dipenuhi di samping syarat lainnya. Di dalam penjelasan Pasal 8 Undang-Undang Perbankan dikatakan bahwa dalam pemberian kredit tidak ada kewajiban bank untuk meminta jaminan tambahan. Karena itu fungsi yuridis materiil suatu jaminan sebagai tindakan preventif itu hampir dapat dikatakan tidak ada. Sehingga timbul peluang-peluang bagi debitur yang mempunyai itikad kurang baik untuk mengambil keuntungan dari celah-celah tersebut. Meskipun menurut ketentuan

\footnotetext{
2008, h.108.

${ }^{5}$ Hasibuan Malayu S. P, Manajemen Sumber Daya Manusia, Jakarta: PT. Bumi Aksara,

6"Bambang Catur P.S., Pengamanan Pemberian Kredit Bank Dengan Jaminan Hak Guna Bangunan, diakses melalui http://journal.uinjkt.ac.id/index.php/citahukum/article/view/1468, pada hari Kamis, pukul 20.54 WIB.
} 
Pasal 8 Undang-Undang Perbankan, jaminan bukan merupakan syarat mutlak dan hanya merupakan salah satu syarat yang harus dipenuhi, namun di dalam kenyataannya dalam pemberian kredit pihak bank selalu mensyaratkan adanya jaminan berupa harta milik debitur. ${ }^{7}$

Jaminan adalah tanggungan yang diberikan oleh debitor dan atau pihak ketiga kepada kreditor karena pihak kreditor mempunyai suatu kepentingan bahwa debitor harus memenuhi kewajiban dalam suatu perikatan. ${ }^{8}$ Jenis jaminan dalam Hukum Perdata dapat dibedakan menjadi dua, yakni jaminan kebendaan dan jaminan perorangan. ${ }^{9}$

Jaminan yang bersifat kebendaan ialah jaminan yang berupa hak mutlak atas sesuatu benda, yang mempuyai ciri-ciri: mempunyai hubungan langsung atas benda tertentu dari debitor, dapat dipertahankan terhadap siapapun, selalu mengikuti bendanya (Droit de suit) yang artinya hak itu akan mengikuti bendanya dimanapun benda itu berada, memiliki asas prioritas yaitu hak yang lahir terlebih dahulu akan diutamakan dari pada hak yang yang lahir kemudian, droit de preference adanya preferensi dan dapat dipertalihkan. ${ }^{10}$ Pihak yang memiliki hak kebendaan ini dalam hal pelunasannnya harus lebih didahulukan pembayarannya, dan gugatannya berupa gugatan kebendaan dimana pemegang jaminan berkedudukan sebagai kreditor preferen yaitu kreditor yang didahulukan pelunasannya. ${ }^{11}$

Jaminan yang bersifat perorangan ialah jaminan yang menimbulkan hubungan langsung pada perorangan tertentu, terhadap harta kekayaan debitur seumumnya. ${ }^{12}$ Jaminan perorangan dengan sebutan penanggungan atau borgtocht yang pengaturannya pada Bab XVII Buku III BW, hak yang dilahirkan adalah hak

\footnotetext{
${ }^{7}$ Djumhaendah Hasan, Lembaga Jaminan Kebendaan Bagi Tanah Dan Benda Lain Yang Melekat Pada Tanah Dalam Konsepsi Penerapan Azas Pemisahan Horisontal, (Bandung: Citra Aditya Bakti, 1996), h. 14

${ }^{8}$ Hasanuddin Rahman, Op. cit, h.162.

9 Sri Soedewi Masjchoen Sofwan, S.H., Hukum Jaminan di Indonesia, Yogyakarta, Liberty Offset, 2003, h.46.

${ }^{10} \mathrm{Ibid}, \mathrm{h} .47$.

${ }^{11}$ Trisadini Prasastinah Usanti dan Leonora Bakarbessy, Hukum Jaminan, Revka Petra Media, Surabaya, 2014, h. 15-16

${ }^{12}$ Sri Soedewi Masjchoen Sofwan, S.H., Op.cit, h.47.
} 
yang bersifat relatif, ${ }^{13}$ yaitu hak yang hanya dapat dipertahankan terhadap orang tertentu yang terikat oleh perjanjian. Dalam jaminan perorangan tidak ada benda tertentu yang diikat dalam perjanjian, karena yang diikat dalam perjanjian adalah kesanggupan pihak ketiga untuk memenuhi kewajiban debitor, sehingga apabila debitor ingkar janji, dalam perjanjian jaminan perorangan berlaku ketentuan jaminan secara umum yang diatur dalam Pasal 1131 BW dan Pasal 1132 BW.

Dalam perjalanan, untuk pemberian kredit dengan jumlah yang sangat besar, untuk menjaga jalannya kredit dengan langkah pengamanan, atas jumlah tertentu yang besar, selain menerima jaminan kebendaan, untuk safeguard dan tentunhya penerapan prinsip kehati-hatian bagi Bank sebagai bagian dari Good Corporaate Governance, bank juga meminta jaminan personal guarantee seperti dalam halnya pinjaman oleh suatu perusahaan kepada bank. Dimana, selain diikat atas hak tanggungan, berupa aset perusahaan yang misalnya berupa Hak Guna Usaha, tetapi bank sebagai perlindungan meminta jaminan perorangan oleh direktur perusahaan.

Yang ingin penulis bahas disini, ialah kedudukan perjanjian Personal Guarantee sebagai jenis perjanjian dan dimana kedudukan serta penjalanan prinsip kehati-hatian bank dengan dilaksanakannya pinjaman berdasar dua jenis jaminan.

\section{Rumusan Masalah}

1. Personal Guarante sebagai jaminan utang dengan objek hak tanggungan

\section{Metode Penelitian}

Penelitian ini menggunakan tipe penelitian doctrinal research, yaitu penelitian ini menghasilkan penjelasan yang sistematis mengenai aturan-aturan hukum yang mengatur suatu kategori hukum tertentu. ${ }^{14}$ Selain itu doctrinal

${ }^{13}$ Trisadini, Op.Cit., h.18.

${ }^{14}$ Terry C. M. Hutchinson, Researching and Writing in Law, Lawbook Company (Thomson Reuters), Sydney, Australia, 2010, h. 10. 
research bertujuan pula sebagai keperluan akademis yaitu peneliti berposisi sebagai pihak yang netral dan sasaran pembacanya adalah akademisi maupun praktisi. Adapun Pendekatan yang digunakan adalah Pendekatan undang-undang (statute approach) yang dilakukan dengan menelaah semua undang-undang dan regulasi yang ada sangkut pautnya dengan isu hukum yang sedang ditangani. Bagi penelitian untuk kegiatan akademis, peneliti perlu mencari ratio legis dan dasar ontologism lahirnya undang-undang tersebut. Sehingga dapat ditemukan suatu aturan yang relevan untuk memecahkan masalah tersebut. ${ }^{15}$ Selain itu peneliti menggunakan Pendekatan konseptual (conceptual approach) dilakukan dengan mencari teori serta doktrin yang telah ada untuk dijadikan suatu acuan agar dapat memahami suatu pandangan-pandangan dan doktrin-doktrin dalam membangun suatu argumentasi hukum dalam memecahkan isu yang sedang dihadapi. ${ }^{16}$

\section{PEMBAHASAN}

\section{Karakteristik Jaminan Hak Tanggungan}

Ketentuan dalam peraturan mewajibkan bank untuk melakukan usaha berdasarkan prinsip kehati-hatian merupakan kewajiban bank untuk tidak merugikan kepentingan nasabah penyimpan dana. Pada hubungan pinjam meminjam antara bank dengan nasabah dan selama dana tersebut dalam penyimpanan di bank maka bank dapat menggunakan dana tersebut, dengan jaminan kepastian bahwa bank mampu mengembalikan, hal tersebut bilamana nasabah menarik dananya, oleh karena itu dalam rangka penyaluran dana dalam bentuk kredit dengan menggunakan dana dari nasabah penyimpan dana maka bank harus cermat dan seksama dalam melakukan analisa kredit terhadap calon

\footnotetext{
${ }^{15}$ Ibid, h. 93-94.

${ }^{16}$ Ibid, h. 95.
} 
nasabah debitor agar dana yang telah disalurkan dapat dilunasi sesuai dengan yang diperanjikan. ${ }^{17}$

Perjanjian yang mengakibatkan perikatan adalah perjanjian obligatoir. Perjanjian yang dimaksud adalah perjanjian pribadi. Dinamakan perjanjian pribadi karena perjanjian hanya mengikat pihak-pihak yang membuatnya saja sesuai dengan ketentuan Pasal 1315 jo 1340 BW. Salah satu contoh dari perjanjian obligatoir adalah perjanjian kredit atau utang. Pengertian kredit sebagaimana disebutkan dalam Pasal 1 angka 11 Undang-Undang Perbankan yaitu penyediaan uang atau tagihan yang dapat dipersamakan dengan itu, berdasarkan persetujuan atau kesepakatan pinjam-meminjam antara bank dengan pihak lain yang mewajibkan pihak peminjam untuk melunasi utangnya setelah jangka waktu tertentu dengan pemberian bunga. Dari penjelasan Pasal tersebut terlihat bahwa perjanjian kredit adalah perjanjian obligatoir.

Dalam pelaksanaan pinjam meminjam uang atau kredit pada umumnya disyaratkan adanya perjanjian tambahan berupa perjanjian jaminan demi keamanan pemberian kredit tersebut. Jaminan utang adalah pemberian keyakinan kepada pihak kreditor atas pembayaran utang-utang yang telah diberikannya kepada debitor, hal ini terjadi karena hubungan hukum terbit dari suatu perjanjian yang bersifat assessoir terhadap perjanjian pokoknya. Mengenai sifat perjanjian jaminan adalah assessoir, yaitu perjanjian tersebut mengikut jaminan pokok berupa perjanjian utang piutang atau kredit. Jenis jaminan utang piutang dapat berupa jaminan kebendaan yang akan menimbulkan hak kebendaan atau jaminan perorangan, biasa disebut dengan borgtocht yang akan menimbulkan hak perorangan. Pada umunya kreditor memilih menggunakan jaminan kebendaan, karena dengan memegang jaminan kebendaan maka kedudukan kreditor akan menjadi kreditor preferen dan hak kebendaan atas jaminan tersebut akan beralih kepada kreditor yang akan memberikan hak untuk mendapat pembayaran utang terlebih dahulu atas eksekusi terhadap benda-benda jamian. Berbeda dengan

\footnotetext{
${ }^{17}$ Trisadini Prasastinah Usanti dan Abd, Shomad, Hukum Perbankan, Lutfansah Mediatama, Surabaya, 2015, h.112 .
} 
jaminan perorangan yang hanya menimbulkan hak perorangan dan hanya dapat dipertahankan kepada pihak yang membuat perjanjian.

Jaminan kebendaan adalah jaminan atas benda tertentu milik debitor atau milik pihak ketiga yang diperuntukan secara khusus bagi kepentingan kreditor tertentu pula. Jaminan kebendaan yang dibuat oleh para pihak adalah perjanjian kebendaan bukan perjanjian obligatoir. ${ }^{18}$ Jaminan kebendaan memiliki beberapa ciri-ciri khusus yang juga merupakan alasan mengapa para kreditor memilih menggunakan jaminan kebendaan daripada jaminan perorangan. Ciri-ciri tersebut antara lain adalah: ${ }^{19}$

a. Bersifat absolut yang berarti dapat ditegakkan kepada siapa saja, tidak hanya pada rekan sekontraknya saja. Berbeda dengan jaminan perorangan yang tidak bersifat absolut sehingga hanya bisa ditegakkan pada rekan sekontraknya saja.

b. Memiliki asas prioritas yang berarti bahwa hak kebendaan yang lahir terlebih dahulu maka akan lebih didahulukan daripada hak yang lahir kemudian.

c. Memiliki asas preferensi yaitu kreditor berhak untuk memperoleh pelunasan terlebih dahulu dibandingkan kreditur lainnya. Kreditor lainnya dalam hak ini adalah kreditor yang tidak memegang hak kebendaan atau kreditor konkuren.

d. Bersifat Droit de Suite yang berarti bahwa hak kebendaan akan mengikuti dimanapun bendanya berada.

Melihat ketentuan dalam Pasal 8 Undang-Undang Perbankan dan penjelasannya, maka arti jaminan pemberian kredit diberikan arti yang lain dengan agunan. Jaminan pemberian kredit diartikan sebagai keyakinnan atas kemampuan dan kesanggupan debitor untuk melunasi utangnya sesuai dengan yang diperjanjikan. Dengan kata lain bahwa Undang-Undang Perbankan telah memberikan arti yuridis bagi jaminan pemberian kredit bukan sebagai agunan kredit, sedangkan agunan kredit hanya merupakan salah satu unsur dari jaminan pemberian kredit.

\footnotetext{
${ }^{18}$ Trisadini Prasastinah Usanti dan Leonora Bakarbessy, Op. Cit., h.11.

${ }^{19} \mathrm{Ibid}$, h. 17.
} 
Jaminan kredit yang selama ini kita kenal dapat berupa jaminan kebendaan dan jaminan perorangan, dalam Undang-Undang Perbankan disebut agunan. Dalam praktik dan dalam tulisan-tulisan mengenai perbankan khususnya kredit perbankan arti yuridis dari jaminan, pemberian kredit sebagaimana yang diatur dalam Undang-Undang Perbankan tidak dipergunakan. Dalam Undang-Undang Perbankan membagi agunan menjadi agunan pokok dan agunan tambahan. ${ }^{20}$

Dalam pelaksanaan perjanjian kredit yang sebagai perjanjian pokok, bank tidak ingin dirugikan, sehingga dalam penerapan prinsip kehati-hatian, bank harus meminta perjanjian jaminan kepada debitor. Guna dari perjanjian jaminan itu agar bank tidak dirugikan apabila debitur tidak bisa melunasi utangnya. Jaminan yang biasanya digunakan untuk melengkapi perjanjian kredit tersebut adalah jaminan kebendaan. Penggunaan jaminan kebendaan ini digunakan kreditur sebagai pemegang jaminan degan kedudukan yang diutamakan atau bank sebagai kreditur preference, karena:

1. "Kreditur didahulukan dan dimudahkan dalam mengambil pelunasan atas tagihannya atau hasil penjualan benda tertentu atau sekelompok benda tertentu milik debitur atau milik pihak ketiga.

2. Ada benda tertentu milik debitur atau pihak ketiga yang dipegang oleh kreditur dan terikat kepada hak kreditur, yang harganya bagi debitur dan dapat memberikan suatu tekanan psikologis terhadap debitur untuk memenuhi kewajibannya dengan baik kreditur."21

Prinsip collateral adalah salah satu prinsip yang seringkali dalam dunia perbankan sebagai salah satu prinsip yang digunakan untuk menjamin kreditur atas pelunasan utang debitur. Risiko dalam pemberian kredit adalah pengembaliannya. Hal tersebut bermula dari kewajiban debitor yang tidak dibayarkan sehingga menimbulkan kredit macet. Maka untuk menambah keyakinan bank dalam memberikan kredit, pada umumnya bank akan

\footnotetext{
${ }^{20}$ Trisadini Prasastinah Usanti dan Leonora Bakarbessy, Op. Cit., h. 17

${ }^{21}$ J.Satrio, Hukum Jaminan, Hak Jaminan Kebendaan, Citra Aditya Bakti, Bandung,
} 2002,h.12. 
mensyaratkan kepada calon debitor untuk menyerahkan jaminan tambahan (agunan). ${ }^{22}$

Sebelum berlakunya Undang-Undang Nomor 5 Tahun 1960 Tentang Peraturan Dasar Pokok-Pokok Agraria (Selanjutnya disebut UUPA), dalam hukum dikenal lembaga-lembaga hak jaminan atas tanah yaitu, jika yang dijadikan jaminan tanah hak barat, seperti Hak Eigendom, Hak Erfpacht atau Hak Opstal, lembaga jaminannya adalah Hipotik, sedangkan Hak Milik dapat sebagai obyek Credietverband. Dengan demikian mengenai segi materilnya mengenai Hipotik dan Credietverband atas tanah masih tetap berdasarkan ketentuanketentuan BW dan Stb 1908 Nomor 542 jo Stb 1937 Nomor 190 yaitu misalnya mengenai hak-hak dan kewajiban yang timbul dari adanya hubungan hukum itu mengenai asas-asas Hipotik, mengenai tingkatan-tingkatan Hipotik janji-janji dalam Hipotik dan Credietverband. ${ }^{23}$

Dengan berlakunya UUPA maka dalam rangka mengadakan unifikasi hukum tanah, dibentuklah hak jaminan atas tanah baru yang diberi nama Hak Tanggungan, sebagai pengganti lembaga Hipotik dan Credietverband dengan Hak milik, Hak Guna Usaha dan Hak Guna Bangunan sebagai obyek yang dapat dibebaninya Hak-hak dalam hukum eropa (Western) sebagai obyek Hipotik dan Hak Milik dapat sebagai obyek Credietverband tidak ada lagi, karena hak-hak tersebut telah dikonversi menjadi salah satu hak baru yang diatur dalam UUPA. Munculnya istilah Hak Tanggungan itu lebih jelas setelah Undang-Undang Nomor 4 Tahun 1996 Tentang Hak Tanggungan (Selanjutnya disebut UndangUndang Hak Tanggungan).

Hak Tanggungan adalah jaminan atas tanah dan tidak termasuk gadai, kreditur hanya menguasai tanah dan rumah secara yuridis saja berdasarkan Undang-undang Hak Tanggungan. Debitur tetap merupakan pemegang hak tanah yang bersangkutan yang menguasai secara yuridis dan fisik hak atas tanah

${ }^{22}$ Utya Prawanirah, Harta Bersama Sebagai Objek Jaminan Kredit Bank, Skripsi, Fakultas Hukum Universitas Airlangga, Surabaya, 2014, h.3.

${ }^{23}$ Sri Soedewi Masjehoen, Hak Jaminan Atas Tanah, Liberty, Yogyakarta, 1975, h. 6 
tersebut. Beranjak dari pengertian di atas, dapat ditarik unsur pokok dari Hak Tanggungan, sebagai berikut: ${ }^{24}$

1. "Objek Hak Tanggungan adalah hak atas tanah sesuai UUPA

2. Hak Tanggungan dapat dibebankan atas tanahnya (hak atas tanah) saja, tetapi dapat pula dibebankan berikut benda-benda lain yang merupakan satu kesatuan dengan tanah itu;

3. Utang yang dijamin adalah suatu utang tertentu;

4. Memberikan kedudukan yang diutamakan kepada kreditur tertentu terhadap kreditur-kreditur lain."

Sebagai salah satu lembaga jaminan, hak tanggungan memiliki ciri kebendaan untuk menjaminkan utang seorang debitur kepada kreditur. Ciri Hak Tanggungan adalah: $^{25}$

1. "Memberikan kedudukan yang diutamakan atau mendahulu kepada pemegangnya atau yang dikenal dengan droit de preference;

2. Selalu mengikuti objek yang dijaminkan dalam tangan siapa pun objek itu berada atau disebut dengan droit de suite. Keistimewaan ini ditegaskan dalam Pasal 7 Undang-Undang Hak Tanggungan. Biarpun objek Hak Tanggungan sudah dipindahkan haknya kepada pihak lain, kreditur pemegang Hak Tanggungan tetap masih berhak untuk menjualnya melalui pelelangan umum jika debitur cedera janji;

3. memenuhi asas spesialitas dan publisitas sehingga dapat mengikat pihak ketiga dan memberikan kepastian hukum bagi pihak yang berkepentingan; dan

4. mudah dan pasti pelaksanaan eksekusinya. Dalam Undang-Undang Hak Tanggungan memberikan kemudahan dan kepastian kepada kreditur dalam pelaksanaan eksekusi."

\footnotetext{
24 http://www.landasanteori.com/2015/09/pengertian-hak-tanggungan definisi.html,
}

Diakses melalui, www.Notaris_Indonesia, (Wadah komunikasi Notaris \& PPAT Indonesia), pada tanggal 4 April 2017, pada pukul 22.44 WIB.

${ }^{25}$ Salim HS, Perkembangan Hukum Jaminan Di Indonesia, RajaGrafindo Persada, Jakarta, 2004, h. 98. 
Apabila mengacu beberapa ketentuan Pasal dari Undang-Undang Hak Tanggungan, maka terdapat beberapa sifat dan asas dari Hak Tanggungan. Adapun sifat dari hak tangggungan adalah sebagai berikut:

1. "Hak Tanggungan mempunyai sifat hak didahulukan, yakni memiliki kedudukan yang diutamakan bagi kreditur tertentu terhadap kreditur lain (droit de preference) dinyatakan dalam pengertian Hak Tanggungan sebagaimana yang diatur dalam Pasal 1 angka 1 Undang-Undang Hak Tanggungan.

2. Hak Tanggungan mempunyai sifat tidak dapat dibagi-bagi. Hak Tanggungan mempunyai sifat tidak dapat dibagi-bagi menurut Pasal 2 ayat (1) Undang-Undang Hak Tanggungan, menentukan: "Hak Tanggungan mempunyai sifat tidak dapat dibagi-bagi, kecuali jika diperjanjikan dalam Akta Pemberian Hak Tanggungan sebagaimana dimaksud pada ayat (2), dan juga di dalam Pasal 2 ayat (2) Undang- Undang Hak Tanggungan.

3. Hak Tanggungan mempunyai sifat membebani berikut atau tidak berikut benda-benda yang berkaitan dengan tanah. Hak Tanggungan dapat dibebankan selain atas tanah juga berikut benda-benda yang berkaitan dengan tanah tersebut sesuai dengan ketentuan yang terdapat dalam Pasal 1 angka 1 Undang-undang Nomor Hak Tanggungan, menentukan bahwa Hak Tanggungan adalah hak jaminan yang dibebankan pada hak atas tanah sebagimana yang dimaksud dalam Undang-undang Nomor 5 Tahun 1960 tentang Peraturan Dasar Pokok-Pokok Agraria, berikut atau tidak berikut benda-benda lain yang merupakan satu kesatuan dengan tanah itu. Hak Tanggungan dapat saja dibebankan bukan saja pada hak atas tanah yang menjadi objek Hak Tanggungan, tetapi juga berikut bangunan, tanaman, dan hasil karya yang merupakan satu kesatuan dengan tanah tersebut.

4. Hak Tanggungan mempunyai sifat Accessoir Hak Tanggungan menurut sifat accessoir dijelaskan dalam penjelasan umum Undang-undang Hak Tanggungan angka 8 menentukan bahwa, "Hak Tanggungan menurut sifatnya merupakan ikutan atau accessoir pada suatu piutang tertentu, yang didasarkan pada suatu perjanjian hutang piutang atau perjanjian lain, maka kelahiran dan keberadaannya ditentukan oleh adanya piutang yang dijamin pelunasannya.

5. Hak Tanggungan mempunyai sifat dapat diberikan lebih dari satu hutang. Hak Tanggungan dapat menjamin lebih dari suatu hutang dinyatakan dalam Pasal 3 ayat (2) Undang-Undang Hak Tanggungan, menentukan: "Hak Tanggungan dapat diberikan untuk suatu hutang yang berasal dari satu hubungan hukum atau untuk satu hutang atau lebih yang berasal dari beberapa hubungan hukum."

6. Hak Tanggungan mempunyai sifat tetap mengikuti objeknya dalam tangan siapapun objek tersebut berada. Hak Tanggungan mengikuti objeknya dalam tangan siapapun objek Hak Tanggungan itu berada berdasarkan Pasal 7 Undang-undang Hak Tanggungan menentukan: "Hak Tanggungan 
tetap mengikuti objeknya dalam tangan siapapun objek tersebut berada". Dengan demikian Hak Tanggungan tidak akan hapus sekalipun objek Hak Tanggungan itu berada pada pihak lain.

7. Hak Tanggungan mempunyai sifat dapat beralih dan dialihkan. Hak Tanggungan dapat beralih dan dialihkan sebagaimana diatur dalam Pasal 16 ayat (1) Undang-Undang Hak Tanggungan, menentukan: "Jika piutang yang dijamin dengan Hak Tanggungan beralih karena cessie, subrogasi, pewarisan, atau sebab-sebab lain. Hak Tanggungan tersebut ikut beralih karena hukum kepada kreditur yang baru. "Hak Tanggungan dapat beralih dan dialihkan karena mungkin piutang yang dijaminkan itu dapat beralih dan dialihkan. Ketentuan bahwa Hak Tanggungan dapat beralih dan dialihkan yaitu dengan terjadinya peralihan atau perpindahan hak milik atas piutang yang dijamin dengan Hak Tanggungan tersebut atau Hak Tanggungan beralih karena beralihnya perikatan pokok."

Hak Tanggungan mempunyai sifat pelaksanaan eksekusi yang mudah Menurut Pasal 6 Undang-undang Hak Tanggungan, menentukan:

"Apabila debitur cidera janji, pemegang Hak Tanggungan pertama mempunyai hak untuk menjual objek Hak Tanggungan dibawah kekuasaan sendiri melalui pelelangan umum serta mengambil pelunasan piutangnya dari hasil penjualan tersebut"

Dengan sifat ini, jika debitur cidera janji maka kreditur sebagai pemegang Hak Tanggungan tidak perlu memperoleh persetujuan dari pemberi Hak Tanggungan, juga tidak perlu meminta penetapan dari pengadilan setempat apabila akan melakukan eksekusi atas Hak Tanggungan yang menjadi jaminan hutang. Pemegang Hak Tanggungan dapat langsung mengajukan permohonan kepada Kepala Kantor Lelang untuk melakukan pelelangan objek Hak Tanggungan yang bersangkutan.

Jaminan perorangan berasal dari kata borgtocht, Sri Soedewi Masjchoen Sofwan mengartikan jaminan perorangan adalah jaminan yang menimbulkan hubungan langsung pada perorangan tertentu, hanya dapat dipertahankan terhadap debitur tertentu, terhadap harta kekayaan debitur umumnya.Dari pengertian di atas, maka dapa diperoleh unsur dari jaminan perorangan, yaitu:

1. Mempunyai hubungan langsung pada orang tertentu;

2. Hanya dapat dipertahankan terhadap debitur tertentu; dan

3. Terdapat harta kekeayaan debitur umumnya. 
Soebekti mengartikan jaminan perorangan adalah suatu perjanjian antara seorang berpiutang (kreditor) dengan seorang ketiga, yang menjamin dipenuhinya kewajiban si berhutang (debitor). Ia bahkan dapat diadakan di luar (tanpa) si berutang tersebut. Dari pengertiannya, Soebekti mengkaji jaminan dari dimensi kontraktual antara kreditur dengan pihak ketiga. Selanjutnya ia mengemukakan, bahwa maksud adanya jaminan ini adalah untuk pemenuhan kewajiban si berhutang, yang dijamin pemenuhannya seluruhnya atau sampai suatu bagian tertentu, harta benda si penanggung (penjamin) dapat disita dan dilelang menurut ketentuan perihal pelaksanaan eksekusi putusan pengadilan.

Dalam jaminan perorangan terdapat empat jenis, yaitu:

1. Penanggung (borg) adalah orang lain yang dapat ditagih;

2. Tanggung-menanggung, yang serupa dengan tanggung renteng;

3. Akibat hak dari tanggung renteng pasif, yaitu bersifat ekstern dan intern. Hubungan hak yang bersifat ekstern yaitu hubungan hak antara para debitur dengan pihak lain dan hubungan hak yang bersifat intern yaitu hubungan hak antara sesame debitur itu satu dengan yang lainnya;

4. Perjanjian garansi, yaitu bertanggungjawab guna kepentingan ketiga. Suatu perjanjian, di mana pihak ketiga demi kepentingan kreditur, mengikatkan dirinya untuk memenuhi perikatan debitur, bila debiur itu tidak memenuhi perikatannya. Dari definisi tersebut,maka jelaslah bahwa ada tiga pihak yang terkait dalam perjanjian penanggungan utang, yaitu pihak kreditur, debitur, dan pihak ketiga. Kreditur berkedudukan sebagai pemberi kredit atau pihak yang berpiutang, debitur berkedudukan sebagai pihak yang menerima kredit atau yang berutang, dan pihak ketiga berkedudukan sebagai penanggung utang debitur. Sebagai penanggung, pihak ketiga bertanggungjawab atas utang debitur ketika wanprestasi.

Pada prinsipnya, pihak ketiga sebagai penanggung tidak mempunyai kewajiban untuk membayar utang debitur kepada kreditur, kecuali jika debitur lalai tidak membayar utangnya. Jadi ketika debitur wanprestasi tidak membayar utannya, maka benda kepunyaan debitur harus disita dan dijual terlebih dahulu untuk melunasi utangnya. 
Penanggungan tidak dapat menuntut supaya barang milik debitur lebih dahulu disita dan dijual untuk melunasi utangnya jika; penanggung utang telah melepaskan hak istimewanya untuk menuntut barang-barang debitur lebih dahulu disita dan dijual, penanggung utang mengikatkan dirinya bersama-sama debitur utama secara tanggung menanggung, debitur dapat mengajukan suatu eksepsi yang hanya mengenai dirinya sendiri secara pribadi, debitur dalam keadaan pailit, dan dalam hal penanggungan yang diperintahkan hakim.

Terdapat beberapa akibat dari penaggungan antara debitur dengan penanggung dan antara para penanggung. Hubungan hukum antara penanggung dengan debitur utama adalah erat kaitannya dengan telah dilakukannya pembayaran utang debitur kepada kreditur. Untuk itu, pihak penanggung menuntut kepada debitur supaya membayar apa yang telah dilakukan oleh penanggung kepada kreditur. Selain itu penaggung utang juga berhak untuk menuntut pokok dan bunga, penggantian biaya, kerugian, dan bunga.

Disamping itu, penanggung juga dapat menuntut debitur untuk diberikan ganti rugi atau untuk dibebaskan dari suatu perikatannya, bahkan sebelum ia membayar utangnya:

1. Bila ia digugat di muka hakim untuk membayar;

2. Bila debitur berjanji untuk membebaskannya dari penanggungannya pada suatu waktu tertentu;

3. Bila uangnya sudah dapat ditagih karena lewatnya jangka waktu yang telah ditetapkan untuk pembayarannya;

4. Setelah lewat waktu sepuluh tahun, jika perikatan pokok tidak mengandung suatu jangka waktu tertentu untuk pengakhirannya, kecuali bila perikatan pokok sedemikian sifatnya, sehingga Stidak dapat diakhiri sebelum lewat waktu tertentu.

\section{PENUTUP}

\section{Kesimpulan}


1. Perjanjian jaminan merupakan perjanjian accessoir yang harus didahului dengan perjanjian pokok, dalam hal ini perjanjian pokoknya adalah perjanjian kredit. Jamian hak tanggungan adalah salah satu lembaga jaminan kebendaan yang banyak digunakan oleh bank untuk melindungi kredit yang diajukan oleh debitor. Pemegang jaminan hak tanggungan ini didahulukan dalam pelunasannya karena termasuk dalam kreditor preferens. Dan jaminan hak tanggungan ini adalah jaminan yang objek hak tanggungan berupa tanah yang telah didaftarkan.

2. Arti dari penanggungan (borgtocht) dapat kita lihat dalam Pasal $1820 \mathrm{BW}$, di mana dikatakan penanggungan ialah suatu persetujuan di mana pihak ketiga demi kepentingan kreditur, mengikatkan diri untuk memenuhi perikatan debitur, bila debitur itu tidak memenuhi perikatannya. Personal guarantee adalah salah satu jenis penanggungan yang mana seseorang menjadi penjamin utang bagi orang lain, hal tersebut biasanya dituangkan dalam akta pembebanan hak tanggungan. Atau dalam hal suatu perusahaan mengajukan utang, maka yang menjadi penanggung adalah direktur dalam perusahaan tersebut. Seperti yang kita ketahui bahwa terdapat pemisahan harta antara perusahaan dan direktur maka apabila harta pribadi direktur yang menjadi objek jaminan hak tanggungan, maka direktur tersebut penjadi personal guarantee atas utang perusahaan.

\section{Saran}

1. Undang-Undang Hak Tanggungan telah sedemikian mengatur tentang jaminan hak tanggungan, baik itu hak dan kewajiban kreditor maupun debitor. Undang-Undang Hak Tanggungan telah sempurna dibuat oleh lembaga yang berwenang. Tetapi dalam pelaksanaannya masih banyak masyarakat yang kurang paham tentang subjek dan objek dari hak tanggungan. Sehingga perlu adanya sosialisasi maupun pengarahan kepada masyarakat yang dapat dilakukan oleh Badan Pertanahan Nasional dan 
Pejabat Pembuat Akta Tanah serta pihak perbankan selaku penyedia fasilitas kredit dengan penerapan prinsip collateral.

2. Penuangan subjek dalam personal guarantee yang merupakan jaminan perorangan harus sedemikian jelas karena dalam hal ini personal guarantee selaku penangguh harus menanggung utang apabila debitor cidera janji. Dan dalam hal ini terdapat dua jaminan yaitu jaminan perorangan dan jaminan kebendaan dalam satu akta yang dibuat oleh pejabat yang berwenang. Sehingga pejabat yang berwenang mengingat suatu objek jaminan hak tanggungan yang dijaminkan oleh personal guarantee harus benar-benar mencerminkan asas spesialitas. 